\title{
Řetězové nárazy vozidel
}

\section{Vehicle Chain Collisions}

\author{
Stanislav Tokař \\ Vysoké učeni technické v Brně, Ústav soudního inženýrstvi
}

\begin{abstract}
Abstrakt
Př́ispěvek se zaměřje na problematiku řetězových nárazů vozidel. Jsou prezentovány nárazové zkoušky provedené za účasti Ústavu soudního inženýrství Vysokého učení technického v Brně. Jedná se zejména o analýzy pohybů vozidel v průběhu vlastního střetu, který je rozdělen na primární a sekundární náraz. Na základě poměru deformačních energií primárního a sekundárního nárazu jsou následně analyzovány rozsahy deformace na jednotlivých vozidlech. Jedná se o přepracovaný a rozšiřrený příspěvek z konference ExFoS 2019 konané v Brně 24. a 25. ledna 2019.
\end{abstract}

Klíčová slova: Řetězový náraz, nárazové parametry, deformace vozidel.

\section{1. ÚVOD}

Tento článek se zabývá problematikou, spadající do forenzních věd, konkrétně do speciální metodiky soudního inženýrství analýzy silničních nehod (dále jen ASN). V rámci technických posudků o prríčinách dopravních nehod se ve většině případů provádí komplexní analýza nehodového děje, jejíž nedílnou součástí je, mimo jiné, řešení vlastního střetu vozidel. V rámci řešení střetu musí znalci správně určit nebo odhadnout deformační energie, vlivem kterých došlo k trvalým deformacím na vozidlech. Tyto hodnoty je možno zjistit např́klad při nárazových zkouškách. V současné době jsou data $z$ homologačních nárazových zkoušek, prováděných v Evropě, v drtivé většině chráněna (napřr. EuroNCAP) a nejsou dostupná pro potřeby expertů zabývajících se ASN. Proto jsou různými organizacemi pro tyto účely prováděny vlastní nárazové zkoušky. Článek představuje výsledky provedených zkoušek řetězových nárazů osobních vozidel, kdy vždy jedoucí vozidlo narazilo do vozidla, před kterým stálo další vozidlo (resp. autobus). Jedním z hlavních vyhodnocovaných parametrů provedených testů byla deformační energie, která byla spotřebována pro vznik trvalých poškození na jednotlivých vozidlech, a její poměr mezi primárním a sekundárním nárazem.

\begin{abstract}
The paper focuses on the issue of chain collisions of vehicles. Presented impact tests are with the participation of the BUT, Institute of Forensic Engineering. These are mainly analyzes of vehicle movements during the crash test, which is divided into primary and secondary impacts. Based on the ratio of deformation energies of primary and secondary impact, the deformation ranges of individual vehicles are analyzed. This is a revised and extended paper from the conference ExFoS 2019 held in Brno on 24 and 25 January 2019.
\end{abstract}

Keywords: chain collisions, impact parameters, vehicle deformation.

Provedené nárazové zkoušky byly uskutečněny pro následující střetové konfigurace vozidel:

1. Opel Vectra B narazil rychlostí cca $36 \mathrm{~km} / \mathrm{h}$ do přední části vozidla Suzuki WagonR+, které následně narazilo zadní části do přední části vozidla Škoda Felicia,

2. Opel Omega B combi narazil rychlostí cca $36 \mathrm{~km} / \mathrm{h}$ do zadní části vozidla Volkswagen Golf III, které následně narazilo přední části do zadní části vozidla Škoda Felicia,

3. Citroën Saxo narazil rychlostí cca $30 \mathrm{~km} / \mathrm{h}$ do zadní části vozidla Volkswagen Golf III, které následně narazilo přední části do zadního rohu autobusu Karosa C 934,

4. Peugeot 406 narazil rychlostí cca $33 \mathrm{~km} / \mathrm{h}$ do zadní části vozidla Ford Fiesta, které následně narazilo přední částí do zadní části vozidla Škoda Felicia.

Početní řešení střetů vozidel je popsáno v mnoha odborných publikacích, můžeme je najít také v literatuře [1]. Metody a postupy použité při vyhodnocení předmětných nárazových zkoušek byly popsány v článku [2].

Jednotlivé nárazové zkoušky byly realizovány v rozpětí let 2012 až 2018. V průběhu této doby se zlepšovala zejména použitá měřicí a dokumentační technika. Byla použita měřící zařízení C-DAQ ÚSI 


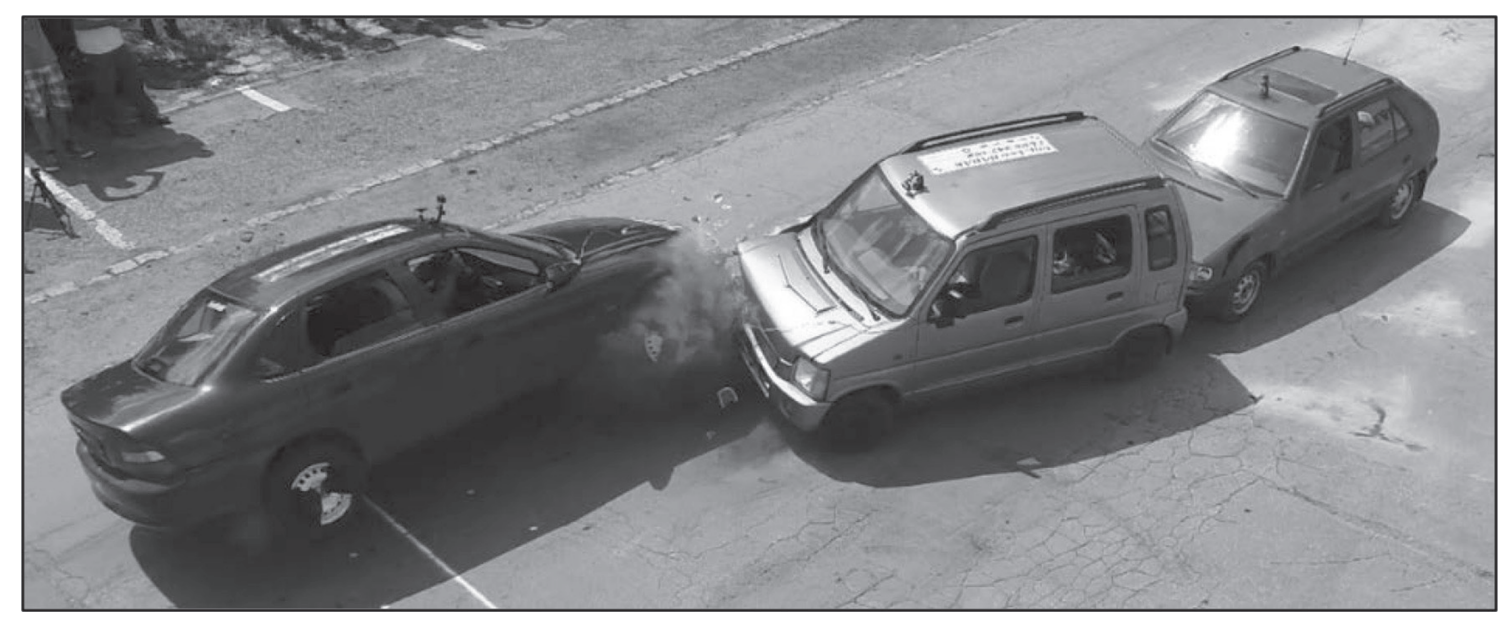

Obr. 1 Nárazová zkouška č. 1 [5].

Fig. 1 Crash test No. 1 [5].

a ÚSI RIO, která byla vyvinuta na Ústavu soudního inženýrství VUT v Brně; dále byly použity měřicí přístroje PicDAQ od společnosti DSD Linz a VBOX Video a Sport od společnosti RaceLogic. $\mathrm{Na}$ vlastní realizaci a zejména dokumentaci nárazových zkoušek se podíleli členové Crashteamu ÚSI VUT, jmenovitě: Ing. Michal Belák, Ing. et Ing. Bc. Martin Bilík, Ph.D., Ing. et Ing. Kateřina Bucsuházy, Ing. Tomáš Coufal, Ph.D., Ing. Roman Mikulec, Ing. Jiř́i Prnka, Ing. Robert Sedlák, Ph.D., doc. Ing. Bc. Marek Semela, Ph.D. a Ing. Lukáš Zemánek, Ph.D.

\section{NÁRAZOVÁ ZKOUŠKA Č. 1}

\subsection{Místo a podmínky zkoušky}

Nárazová zkouška č. 1 byla provedena dne 21. 6. 2018 v areálu Vyšší odborné školy a Střední školy automobilní v Zábřehu na Moravě v rámci akce Otevřeného týdne - Crashday. Pořadateli crash testů byli znalci Ing. Ivan Krejsa a Ing. Leo Dadák, který byl také testovacím jezdcem. Vozidla byla při nárazové zkoušce osazena záznamovým měřcím zařízením ÚSI RIO se záznamovou frekvencí $50 \mathrm{kHz}$.

\subsection{Průběh nárazové zkoušky}

Při tomto testu došlo k nárazu předního pravého rohu vozidla Opel Vectra, pohybujícího se rychlostí cca $36 \mathrm{~km} / \mathrm{h}$, do pravého předního rohu stojícího vozidla Suzuki Wagon R+. Vzájemné překrytí př̀edních částí vozidel bylo cca 20 až $25 \%$, tedy jednalo se o tzv. „Small over lap crash test" tedy náraz s malým překrytím. $V$ důsledku primárního nárazu bylo vozidlo Suzuki odhozeno a narazilo svou zadní části rychlostí cca $20 \mathrm{~km} / \mathrm{h}$ do přední části vozidla Škoda Felicia, které stálo 1,8 m za vozidlem Suzuki. Průběh nárazu je znázorněn na obr. 1 . Počáteční a konečné polohy vozidel byly zadokumentovány pomocí GNSS př́stroje CHC X91, viz obr. 2.

Na grafech v obr. 3 až 6 jsou zpracovány průběhy sledovaných veličin při nárazu vozidel z měřícího zařízení ÚSI RIO, které byly zpracovány pomocí software DIAdem od společnosti National Instruments.

\subsection{Výsledky testu a poškození vozidel}

Pro vyhodnocení parametrů „ekvivalentní energetické rychlosti“ vozidel (EES) jako ekvivalentu energie, která způsobí obdobné trvalé deformace vozidel, bylo vycházeno z předpokladu rovnoměrného rozdělení deformační energie mezi kolizní partnery. Tento předpoklad byl podpořen také velmi obdobnými hloubkami deformací resp. rozsahy deformací.

Poškození vozidel svým rozsahem odpovídala také obdobně poškozeným vozidlům v EES katalogu. Tato dobrá shoda byla způsobena zejména obdobným stářím a konstrukční vyspělostí vozidel. Poškození přední části vozidla Škoda bylo charakteristické pro náraz od tažného zařízení, které bylo na vozidle Suzuki.

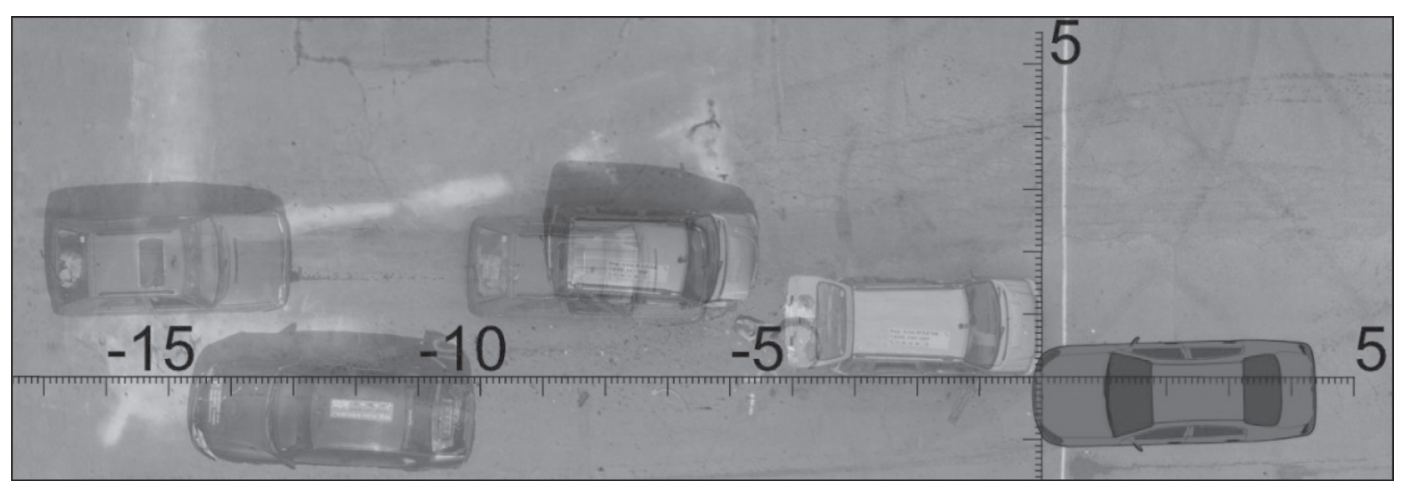

Obr. 2 Počátečni a konečné polohy vozidel - zkouška č. 1 [5].

Fig. 2 Start and final position of vehicles - test No. 1 [5]. 


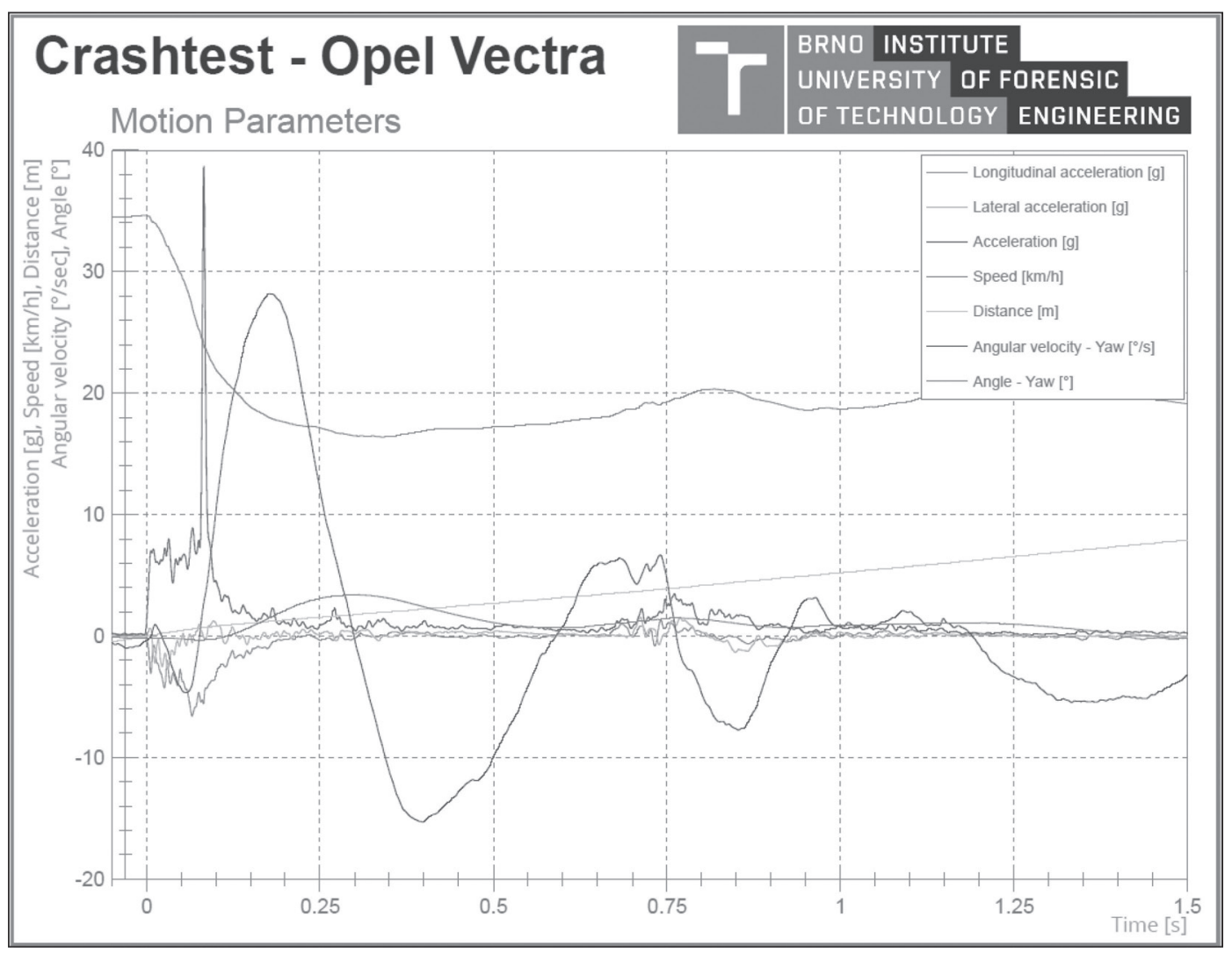

Obr. 3 Parametry pohybu vozidla Opel Vectra-zkouška č. 1 (zrychlení, rychlost, dráha, úhel natočení, stáčívá rychlost) [5].

Fig. 3 Parameters of vehicle motion Opel Vectra - test No. 1 (acceleration, speed, distance, angle, angular velocity) [5].

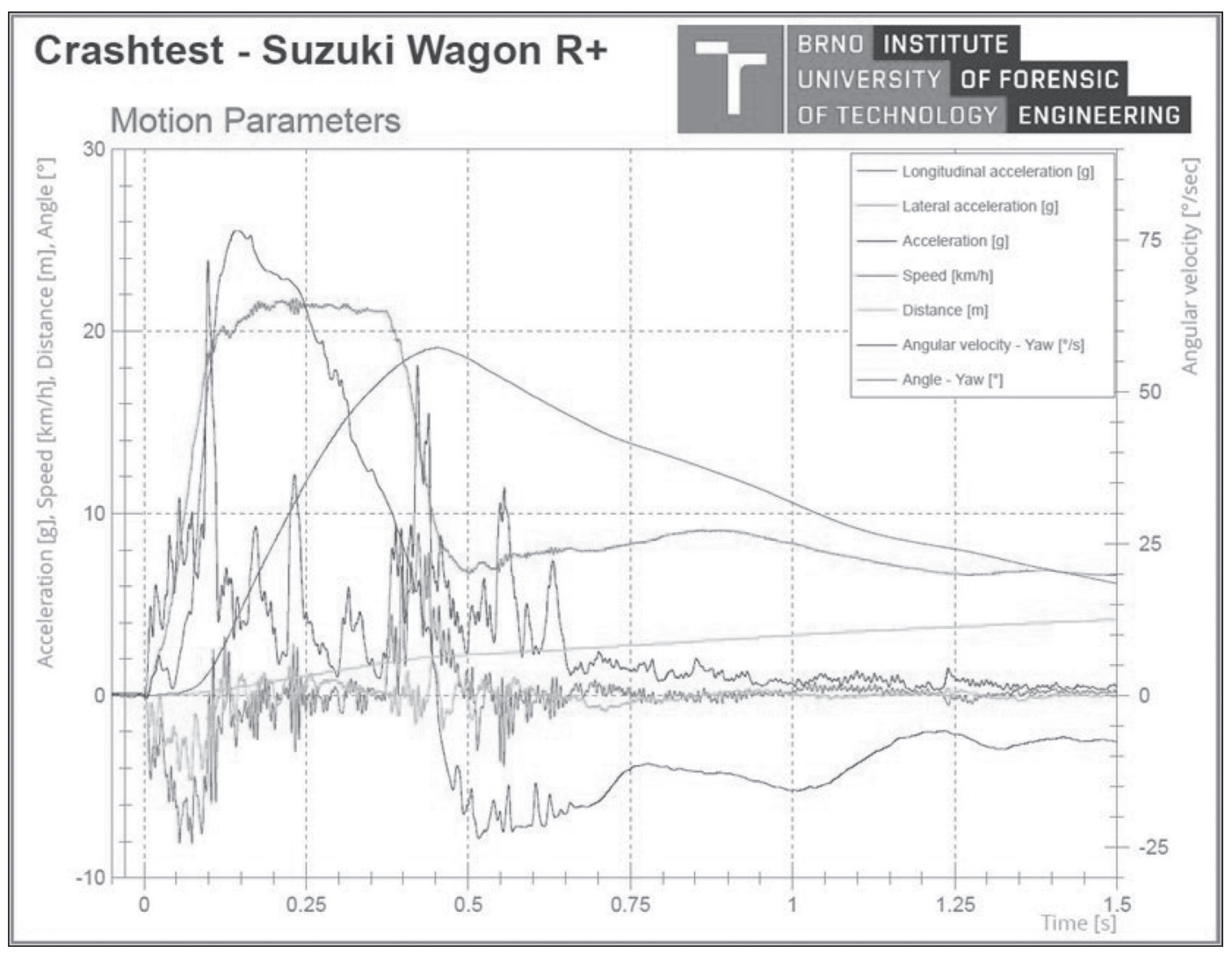

Obr. 4 Parametry pohybu vozidla Suzuki Wagon R+-zkouška č. 1 (zrychlení, rychlost, dráha, úhel natočení, stáčivá rychlost) [5].

Fig. 4 Parameters of vehicle motion Suzuki Wagon $R+-$ test No. 1 (acceleration, speed, distance, angle, angular velocity) [5]. 


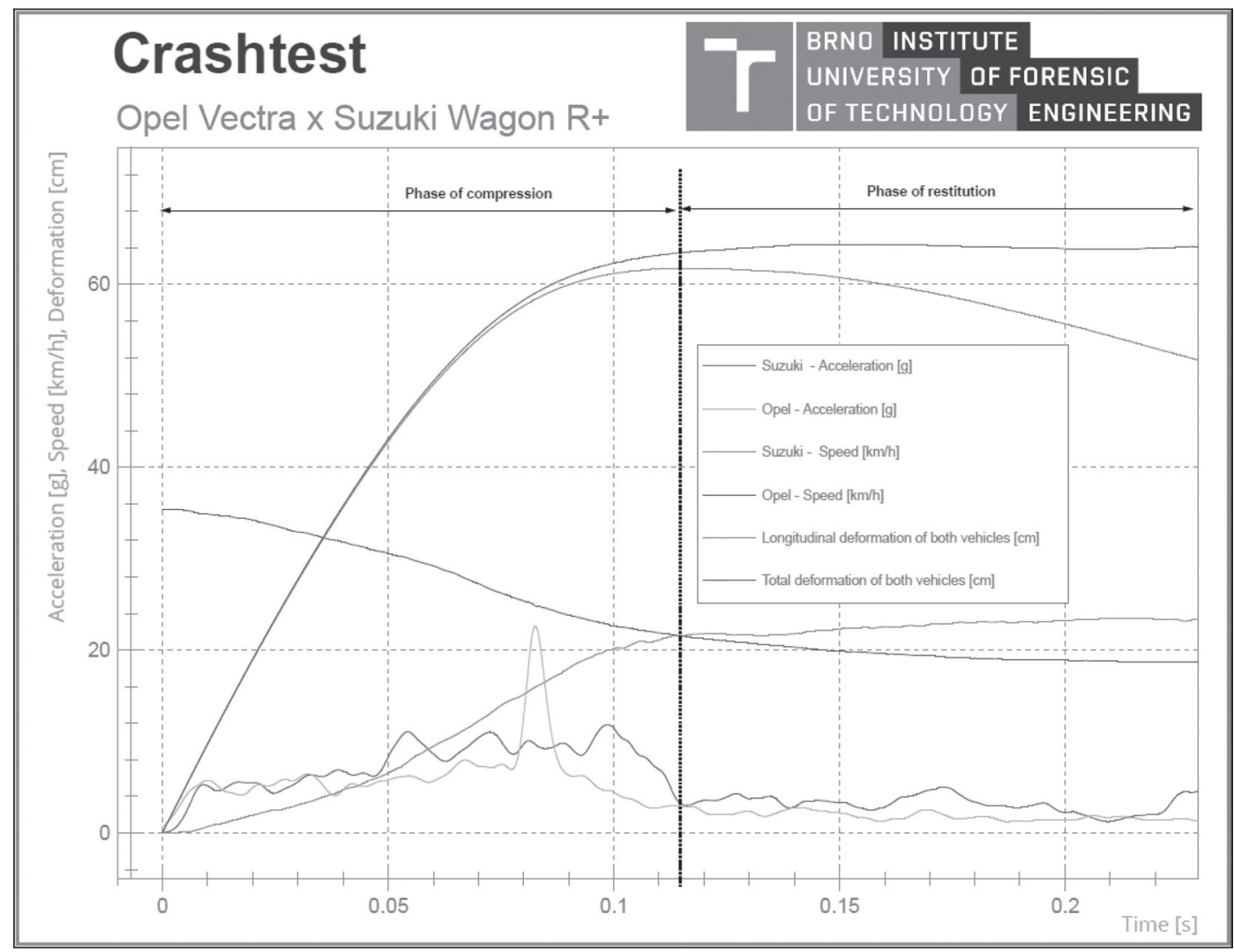

Obr. 5 Parametry střetu vozidel Opel a Suzuki-zkouška č. 1 (zrychlení, rychlosti, hloubka deformace) [5].

Fig. 5 Parameters of collision vehicles Opel and Suzuki - test No. 1 (acceleration, speed, deformation of both vehicles) [5].

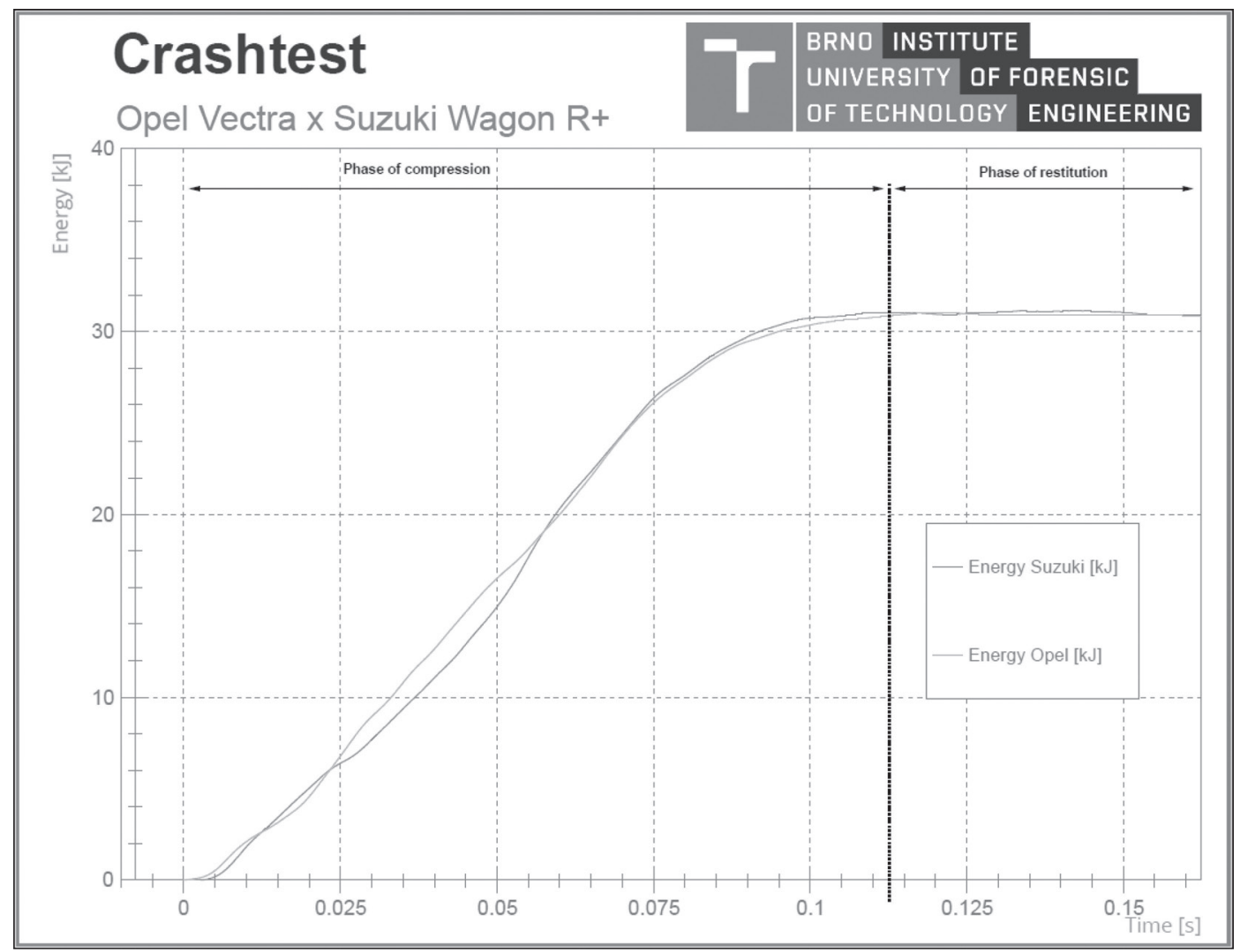

Obr. 6 Parametry střetu vozidel Opel a Suzuki-zkouška č. 1 (deformační energie) [5].

Fig. 6 Parameters of collision vehicles Opel and Suzuki - test No. 1 (deformation energy) [5]. 
Tab. 1 - Parametry vozidel, střetů a postřetových pohybů-zkouška č. 1 [5].

Tab. 1 -Parameters of vehicles, crash parameters and after crash moving vehicles - test No. 1 [5].

\begin{tabular}{lccc}
\hline Parametr / vozidlo & Opel Vectra B & Suzuki Wagon R+ & Škoda Felicia \\
\hline Hmotnost $[\mathrm{kg}]$ & 1425 & 1055 & 920 \\
Střetová rychlost $[\mathrm{km} / \mathrm{h}]$ & 36 & $0 / 20$ & 0 \\
Postřetová rychlost $[\mathrm{km} / \mathrm{h}]$ & 18 & 20 & 7 \\
Deformační energie $[\mathrm{kJ}]$ & Edef $1=$ cca 30,5 & \multicolumn{2}{c}{ Edef $2=5,4$} \\
EES $[\mathrm{km} / \mathrm{h}]$ & cca 17 & cca $19 /$ cca 8 & cca 9 \\
Postřetová dráha $[\mathrm{m}]$ & 13,5 & 4,6 & 6,7 \\
\hline
\end{tabular}
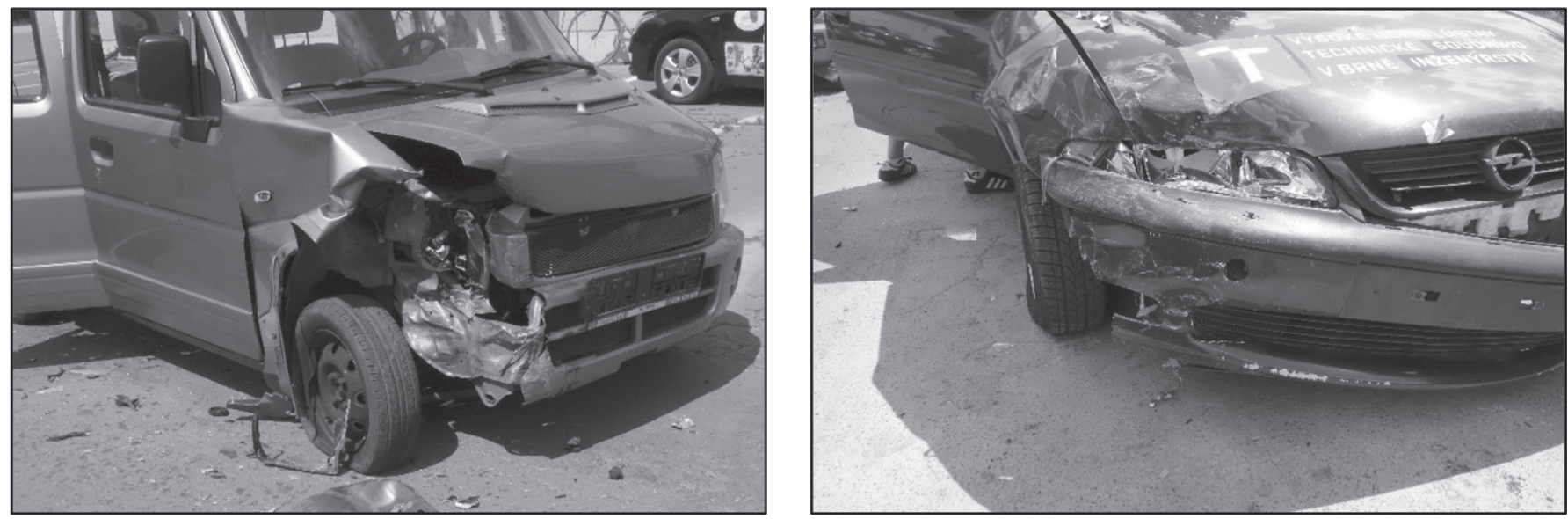

Obr. 7 a 8 Poškození vozidel Opel a Suzuki při prvním nárazu zkouška č. 1 [5].

Fig. 7 and 8 Damage of vehicles Opel and Suzuki at first collision-test No. 1 [5].
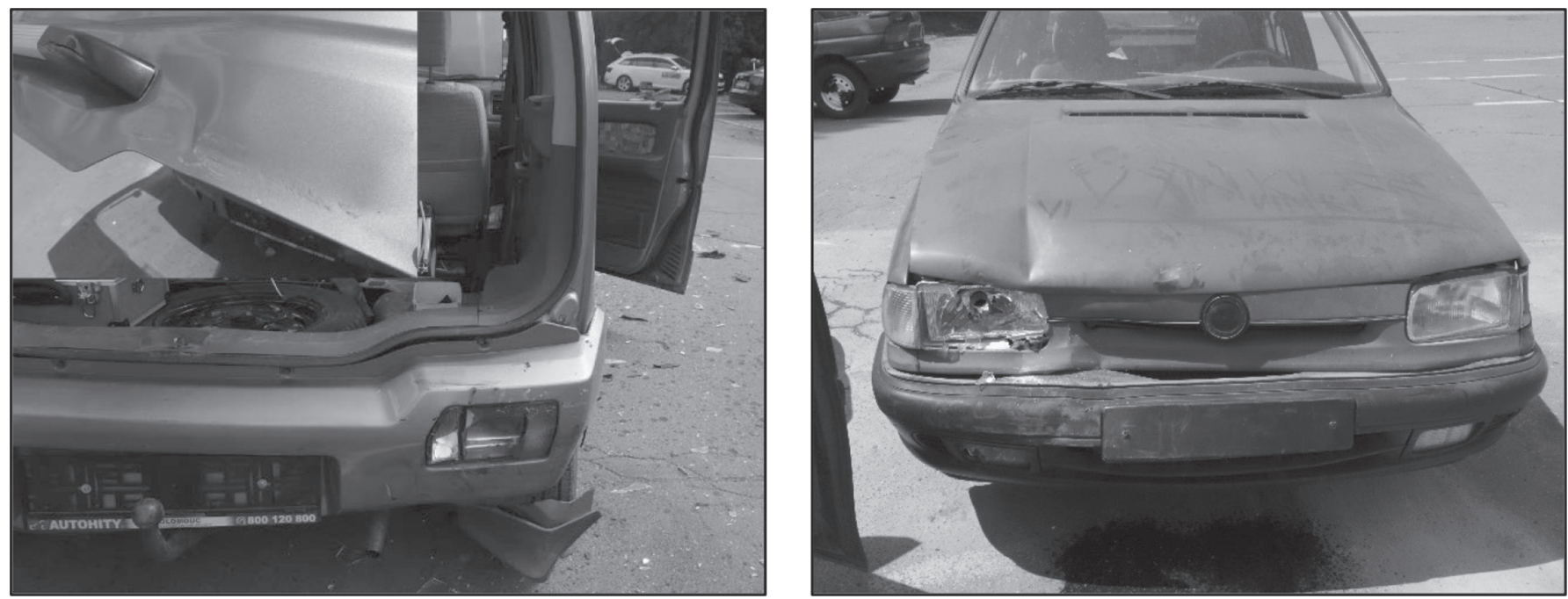

Obr. 9 a 10 Poškození vozidel Suzuki a Škoda při druhém nárazu zkouška č. 1 [5].

Fig. 9 and 10 Damage of vehicles Suzuki and Skoda at second collision-test No. 1 [5]

\section{NÁRAZOVÁ ZKOUŠKA Č. 2}

\subsection{Místo a podmínky zkoušky}

Nárazová zkouška č. 2 byla součástí testů provedených dne 3. 10. 2012 v areálu bývalých letištních skladů v Pardubicích. Byla součásti dvoudenního programu, zaměřeného na nárazové zkoušky pro účely zaměstnanců pojišt’oven, zabývajících se likvidací škodních události v oblasti pojištění motorových vozidel.
Organizátorem a testovacím jezdcem byl znalec Bc. Daniel Pýcha. Tato akce byla jednou z prvních, na kterých bylo testováno záznamové zařízení C-DAQ ÚSI.

\subsection{Průběh nárazové zkoušky}

Nárazová zkouška č. 2 byla provedena pohybujícím se vozidlem Opel Omega B combi, které se na počátku nárazu pohybovalo rychlostí cca $36 \mathrm{~km} / \mathrm{h}$. Svým levým předním rohem narazilo 


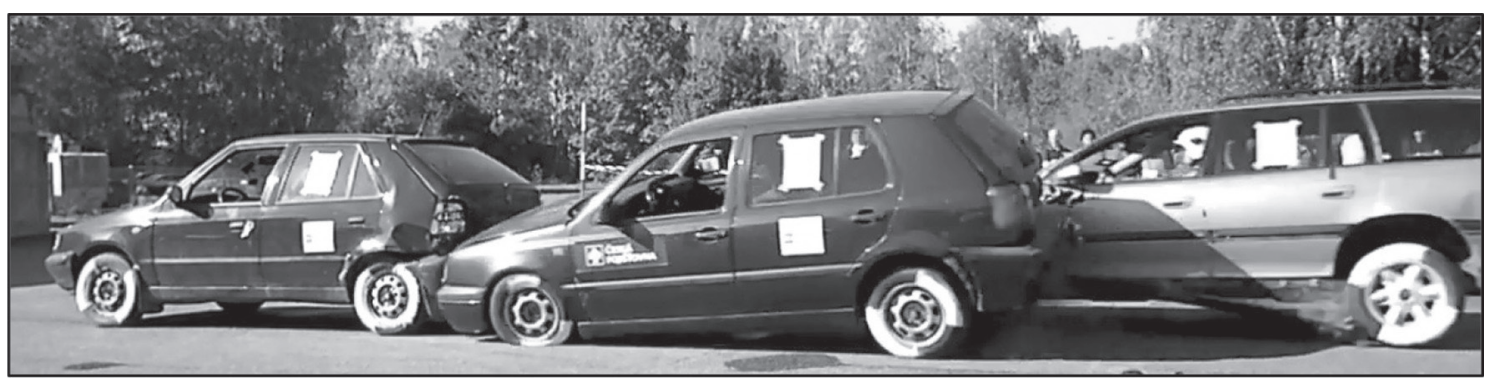

Obr. 11 Nárazová zkouška č. 2 [6].

Fig. 11 Crash test No. 2 [6].

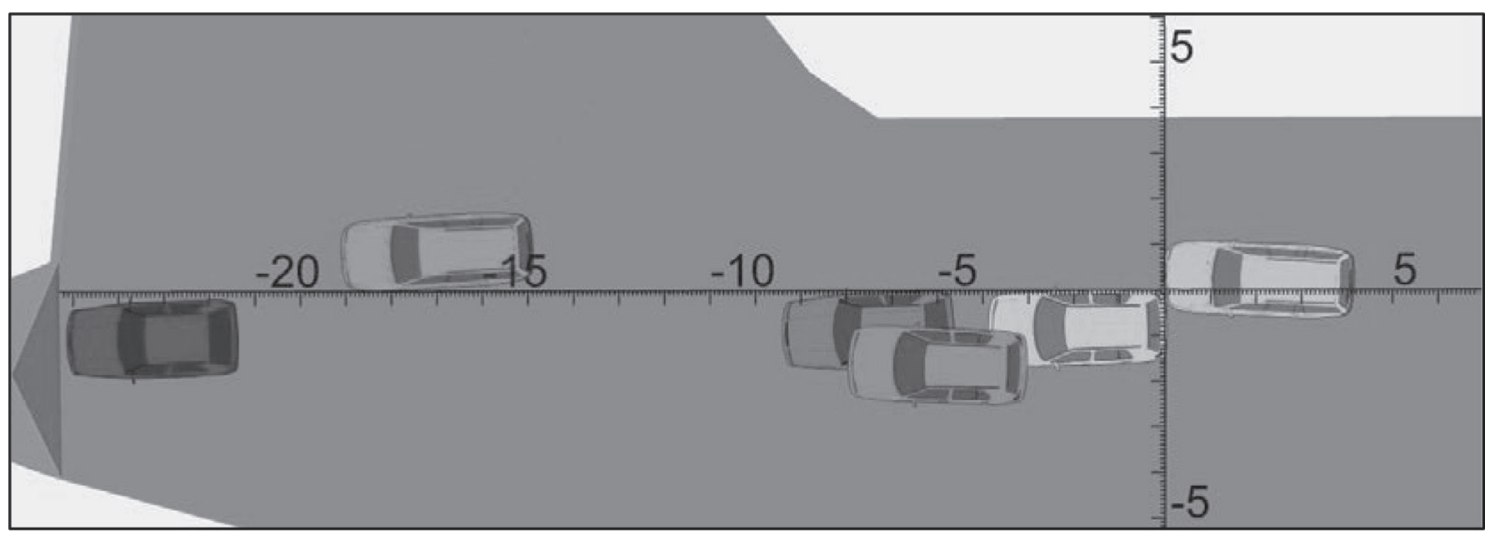

Obr. 12 Počáteční a konečné polohy vozidel-zkouška č. 2 [6].

Fig. 12 Start and final position of vehicles - test No. 2 [6].

do pravého zadního rohu vozidla Volkswagen Golf III, které bylo nárazem odhozeno a svou přední části narazilo do zadní části vozidla Škoda Felicia, stojícího cca $1 \mathrm{~m}$ před ním. Vlastní průběh řetězového nárazu vozidel je znázorněn na obr. 11. Počáteční a koncové polohy vozidel byly zaměřeny geodetickou totální stanicí TOPCON GPT-212 a jsou znázorněny na obr. 12. Primární kontakt vozidel Opel Omega a Volkswagen Golf byl proveden s malým překrytím cca 20 až $25 \%$.

Při analýze dat z nárazového testu bylo bohužel zjištěno, že datový soubor z měřicího zařízení C-DAQ ÚSI, umístěného ve vozidle Opel, vykazoval neopravitelnou chybu. Výchozí rychlost vozidla Opel byla stanovena na základě rozboru videa. Střetové konfigurace a konečné polohy vozidel musely odpovídat údajům z geodetické totální stanice. Následně byla provedena simulace průběhu nárazové zkoušky s podporou simulačního programu Virtual CRASH 4 na zaměřeném polygonu. Provedená analýza byla zcela $\mathrm{v}$ souladu s video a fotodokumentací nárazové zkoušky. Postřetová dráha vozidla Opel byla ovlivněna skutečností, že při nárazu do vozidla Volkswagen došlo k destrukci zavěšení levého předního kola, poškození rízení a zřejmě také k poškození brzdové soustavy, proto vozidlo po střetu výrazně nezpomalovalo (nebrzdilo). Postřetová dráha vozidla Škoda Felicia byla způsobena skutečností, že vozidlo nebylo výrazně brzděno (nebyla zatažena ruční brzda ani nebyl zařazen rychlostní stupeň) a do své konečné polohy dojelo minimální rychlostí.

\subsection{Výsledky testu a poškození vozidel}

Střetové parametry vozidel byly vypočteny s podporou simulačního programu Virtual Crash [3] tak, aby průběh nárazu a postřetový pohyb vozidel zcela odpovídal zadokumentovaným skutečnostem. Hodnoty EES byly stanoveny na základě deformační energie a s využitím komparační metody, kdy je poškození skutečného vozidla srovnáváno s poškozením vozidel z katalogů, u kterých je známa jejich EES a také jejich hmotnost.

Vozidlo Škoda Felicia bylo již před tímto nárazovým testem poškozeno ve své zadní části. Proto bylo také stanovení parametru

Tab. 2 - Parametry vozidel, střetů a postřetových pohybů-zkouška č. 2 [6].

Tab. 2 - Parameters of vehicles, crash parameters and after crash moving vehicles - test No. 2 [6].

\begin{tabular}{llll}
\hline Parametr / vozidlo & Opel Omega B combi & Volkswagen Golf III & Škoda Felicia \\
\hline Hmotnost $[\mathrm{kg}]$ & 1750 & 1040 & 925 \\
Střetová rychlost $[\mathrm{km} / \mathrm{h}]$ & 36 & $0 / 16$ & 0 \\
Postř́tová rychlost $[\mathrm{km} / \mathrm{h}]$ & 27 & 16 & 8 \\
Deformační energie $[\mathrm{kJ}]$ & Edef1 = cca 27 & \multicolumn{2}{c}{ Edef $2=3,2$} \\
EES $[\mathrm{km} / \mathrm{h}]$ & cca 17 & cca $13 /$ cca 7 & cca 7 \\
Postřetová dráha $[\mathrm{m}]$ & 18,5 & 3,4 & 16 \\
\hline
\end{tabular}



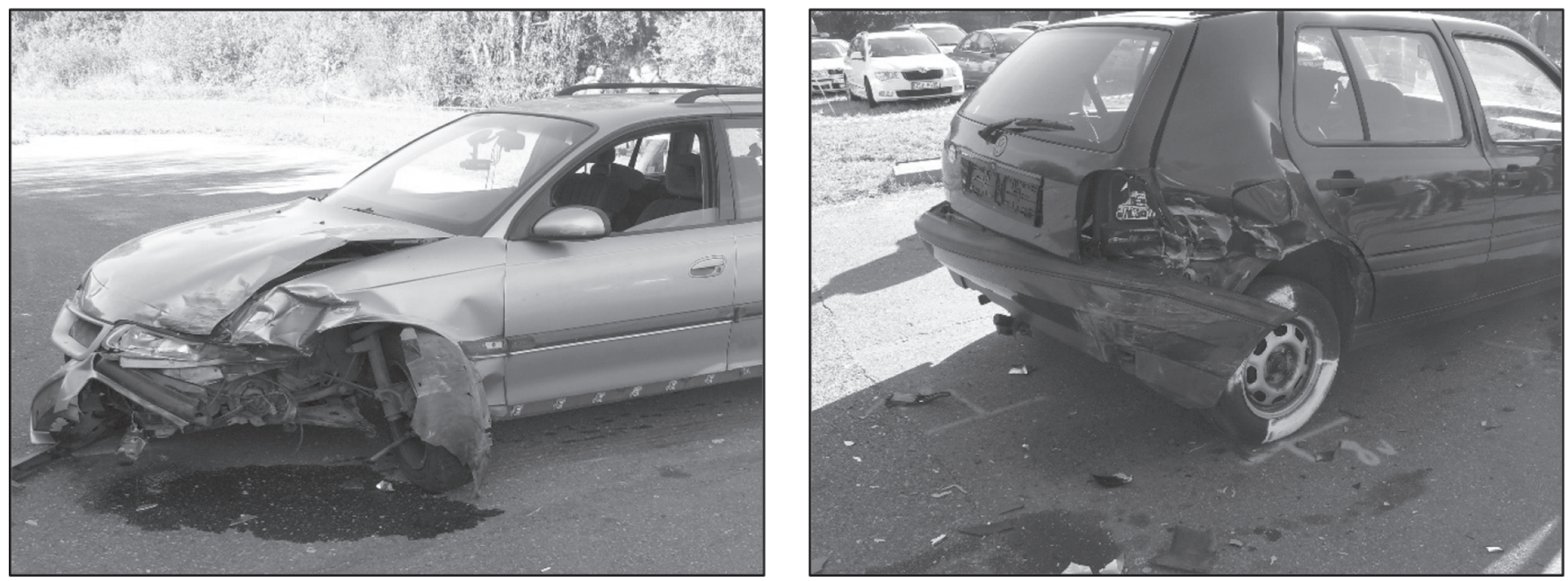

Obr. 13 a 14 Poškození vozidel Opel a Volkswagen při prvním nárazu zkouška č. 2 [6].

Fig. 13 and 14 Damage of vehicles Opel and Volkswagen at first collision - test No. 2 [6].
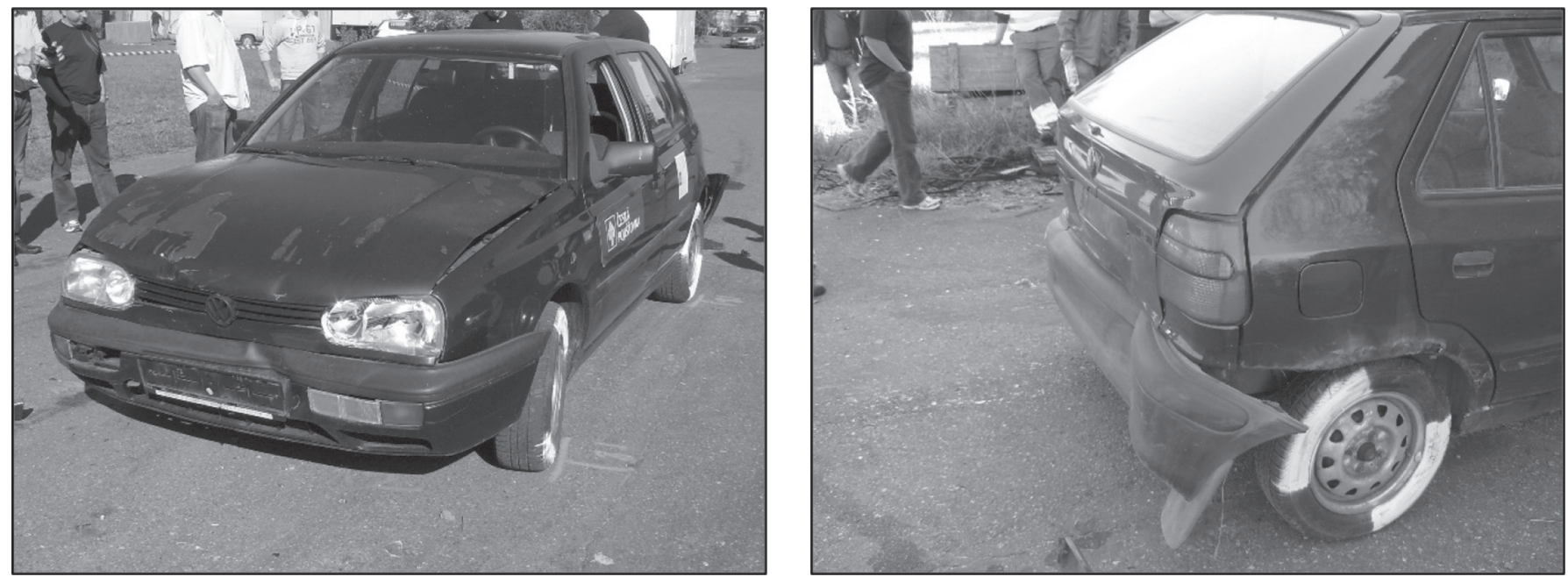

Obr. 15 a 16 Poškození vozidel Volkswagen a Škoda při druhém nárazu zkouška č. 2 [6].

Fig. 15 and 16 Damage of vehicles Volkswagen and Skoda at second collision-test No. 2 [6].

EES velmi obtížné. Bylo tedy vycházeno z předpokladu rovnoměrného rozdělení deformační energie na obě vozidla.

\section{NÁRAZOVÁ ZKOUŠKA Č. 3}

\subsection{Místo a podmínky zkoušky}

Předmětná nárazová zkouška se uskutečnila dne 16. 6. 2016 v areálu společnosti Haná metal v Prostějově. Jednalo se o nárazové zkoušky pořádané znalci Ing. Ivanem Krejsou a Ing. Leo Dadákem za účelem ověřovaní skutečností, potřebných pro vypracování znaleckých posudků. Pro záznam nárazové zkoušky bylo ve vozidle Citroën Saxo umístěno záznamové zařízení PicDaq.

\subsection{Průběh nárazové zkoušky}

Vozidlo Citroën Saxo bylo pomocným vozidlem roztlačeno na nárazovou rychlost cca $30 \mathrm{~km} / \mathrm{h}$. Vozidlo Citroën narazilo svou přední části téměř s plným překrytím do zadní části stojícího vozidla Volkswagen Golf, které bylo nárazem urychleno na rychlost cca $17 \mathrm{~km} / \mathrm{h}$. Touto rychlostí narazilo svou přední částí do levého zadního rohu autobusu Karosa C 934. Následně byla vozidla Volkswagen a Citroën odražena zpět do svého původního směru pohybu. Tento odraz nastal zejména $\mathrm{v}$ důsledku propružení pneumatik a zavěšení na autobusu Karosa. Po zpětném odrazu od autobusu vozidla dojela do konečných poloh velmi nízkou rychlostí cca 3 až 4 km/h. Průběh nárazové zkoušky je znázorněn na obr. 17. Zadokumentované polohy vozidel před nárazem a v konečných polohách jsou na obr. 18 a byly pořízeny pomocí kvadrokoptéry.

\subsection{Výsledky testu a poškození vozidel}

$\mathrm{V}$ tab. 3 jsou uvedeny parametry střetů a postřetových pohybů vozidel. Velmi obtížným se jevila kvantifikace rozsahu deformace na autobusu Karosa, který vzhledem k násobně větší hmotnosti autobusu vůči koliznímu partnerovi byl uvažován velmi nízký. Rozsah poškození přední části vozidla Volkswagen při nárazu do levého zadního rohu autobusu byl také $\mathrm{v}$ dobrém souladu s obdobně poškozenými vozidly v EES katalogu.

Poškození přední části vozidla Citroën bylo charakteristické pro náraz od tažného zařízení, které bylo na vozidle Volkswagen. 


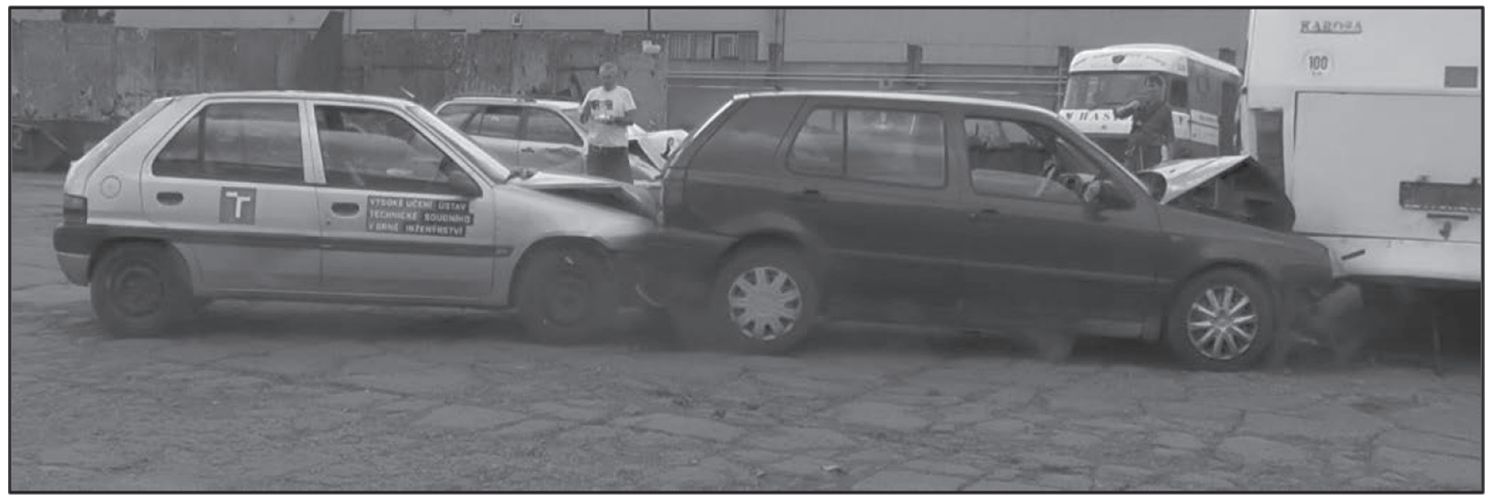

Obr. 17 Nárazová zkouška č. 3 [7].

Fig. 17 Crash test No. 3 [7].

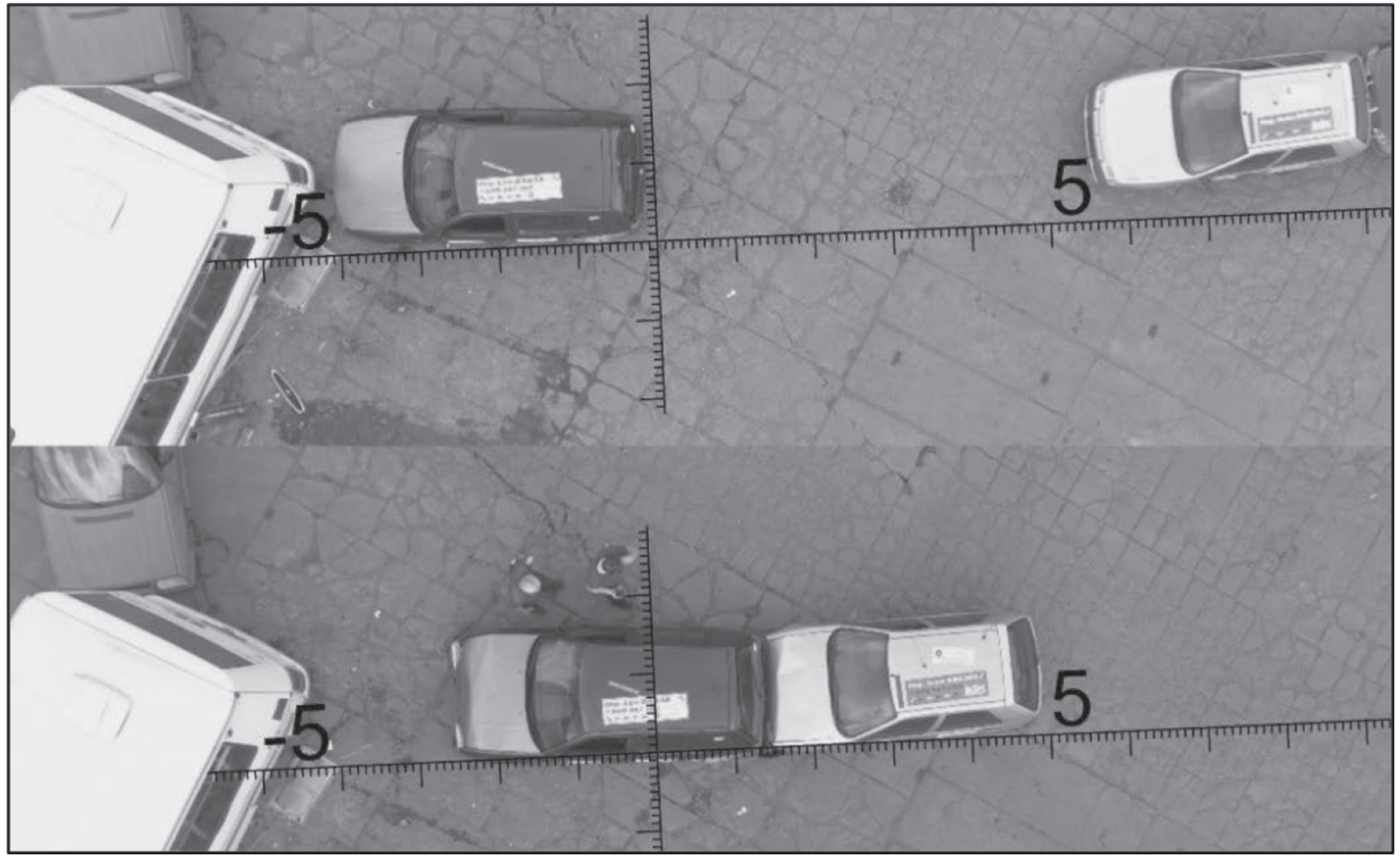

Obr. 18 Počáteční a konečné polohy vozidel-zkouška č. 3 [7].

Fig. 18 Start and final position of vehicles - test No. 3 [7].
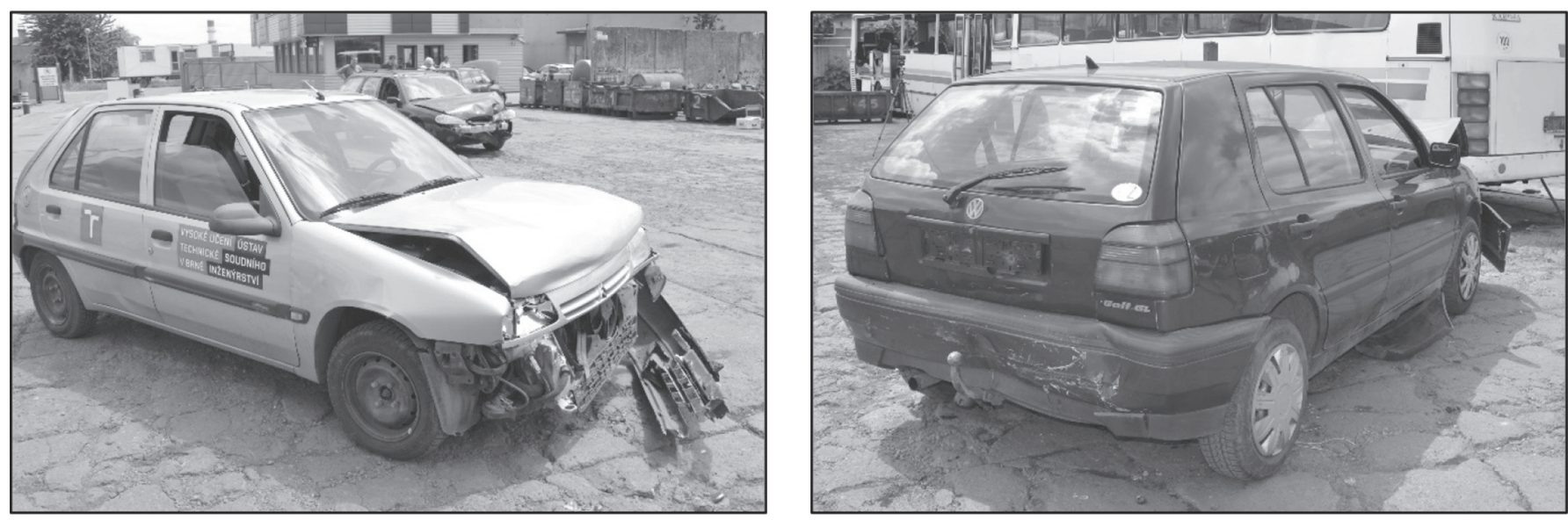

Obr. 19 a 20 Poškození vozidel Citroën a Volkswagen při prvním nárazu zkouška č. 3 [7].

Fig. 19 and 20 Damage of vehicles Citroën and Volkswagen at first collision-test No. 3 [7]. 

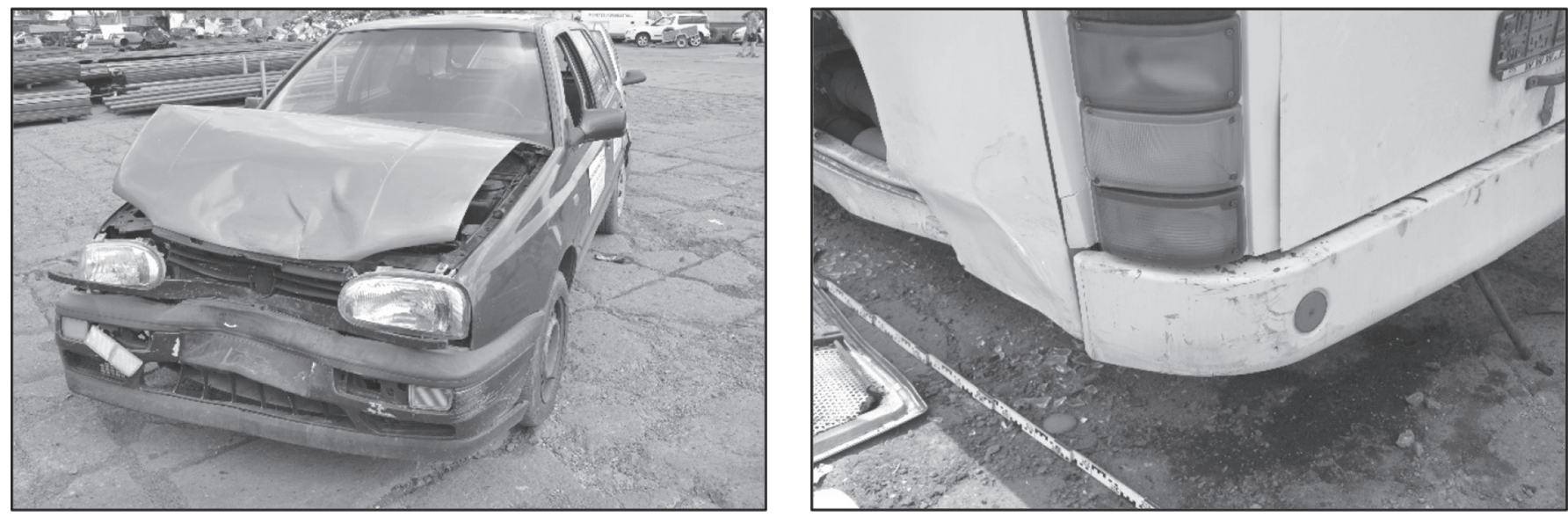

Obr. 21 a 22 Poškození vozidla Volkswagen a autobusu Karosa při druhém nárazu zkouška č. 3 [7].

Fig. 21 and 22 Damage of vehicle Volkswagen and bus Karosa at second collision - test No. 3 [7].

Tab. 3 - Parametry vozidel, střetů a postřetových pohybů-zkouška č. 3 [7].

Tab. 3 - Parameters of vehicles, crash parameters and after crash moving vehicles - test No. 3 [7].

\begin{tabular}{lccc}
\hline Parametr / vozidlo & Citroën Saxo & Volkswagen Golf III & Karosa C 934 E \\
\hline Hmotnost $[\mathrm{kg}]$ & 880 & 1127 & 11000 \\
Střetová rychlost $[\mathrm{km} / \mathrm{h}]$ & 30 & $0 / 17$ & 0 \\
Postřetová rychlost $[\mathrm{km} / \mathrm{h}]$ & 8 & 16 & 0 \\
Deformační energie $[\mathrm{kJ}]$ & Edefl $=$ cca 14,8 & Edef $2=8,4$ \\
EES $[\mathrm{km} / \mathrm{h}]$ & $\mathrm{cca} 14$ & cca $14 / \mathrm{cca} 13$ & cca 1,5 \\
Postřetová dráha $[\mathrm{m}]$ & $-1,3$ & $-1,3$ & 0 \\
\hline
\end{tabular}

\section{NÁRAZOVÁ ZKOUŠKA Č. 4}

\subsection{Místo a podmínky zkoušky}

Nárazová zkouška se uskutečnila 23. 5. 2018 v Pardubicích. Jednalo se o nárazové zkoušky pořádané znalci $\mathrm{Bc}$. Danielem Pýchou a Ing. Vlastimilem Rábkem, Ph.D. pro účely školení zaměstnanců pojišt’oven, zabývajících se likvidací škodních události v oblasti pojištění motorových vozidel.

\subsection{Průběh nárazové zkoušky}

Vozidlo Peugeot 406 bylo řízeno a narazilo rychlostí cca $33 \mathrm{~km} / \mathrm{h}$ svou přední části téměř s plným překrytím do zadní části $\mathrm{v}$ tu

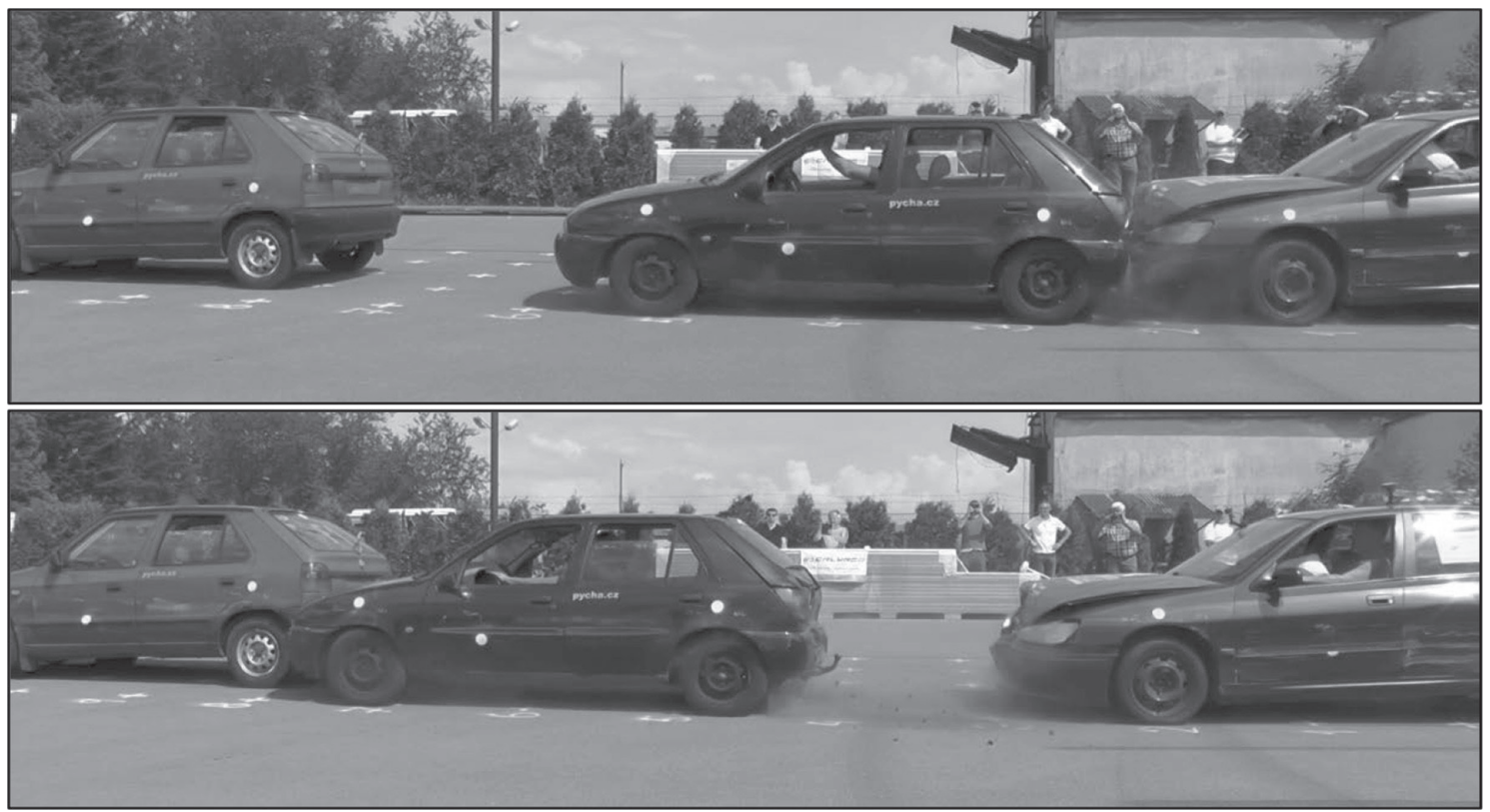

Obr. 23 Nárazová zkouška č. 4 [8].

Fig. 23 Crash test No. 4 [8]. 


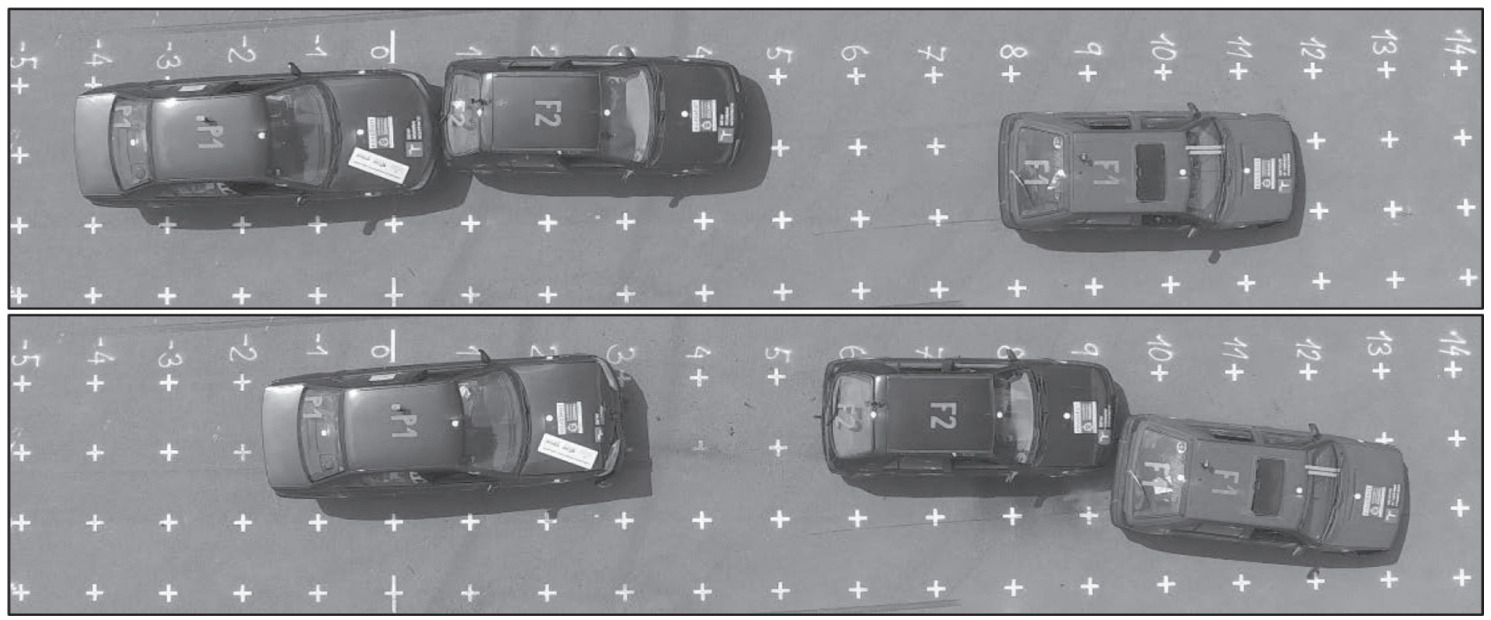

Obr. 24 Počátečni a konečné polohy vozidel -zkouška č. 4 [8].

Fig. 24 Start and final position of vehicles - test No. 4 [8].

Tab. 4 - Parametry vozidel, střetů a postřetových pohybů - zkouška č. 4 [8].

Tab. 4 - Parameters of vehicles, crash parameters and after crash moving vehicles - test No. 4 [8]

\begin{tabular}{lccc}
\hline Parametr / vozidlo & Peugeot 406 & Ford Fiesta & Škoda Felicia \\
\hline Hmotnost $[\mathrm{kg}]$ & 1340 & 1060 & 1000 \\
Střetová rychlost $[\mathrm{km} / \mathrm{h}]$ & 33 & $0 / 18$ & 0 \\
Postřetová rychlost $[\mathrm{km} / \mathrm{h}]$ & 17 & 18 & -
\end{tabular}
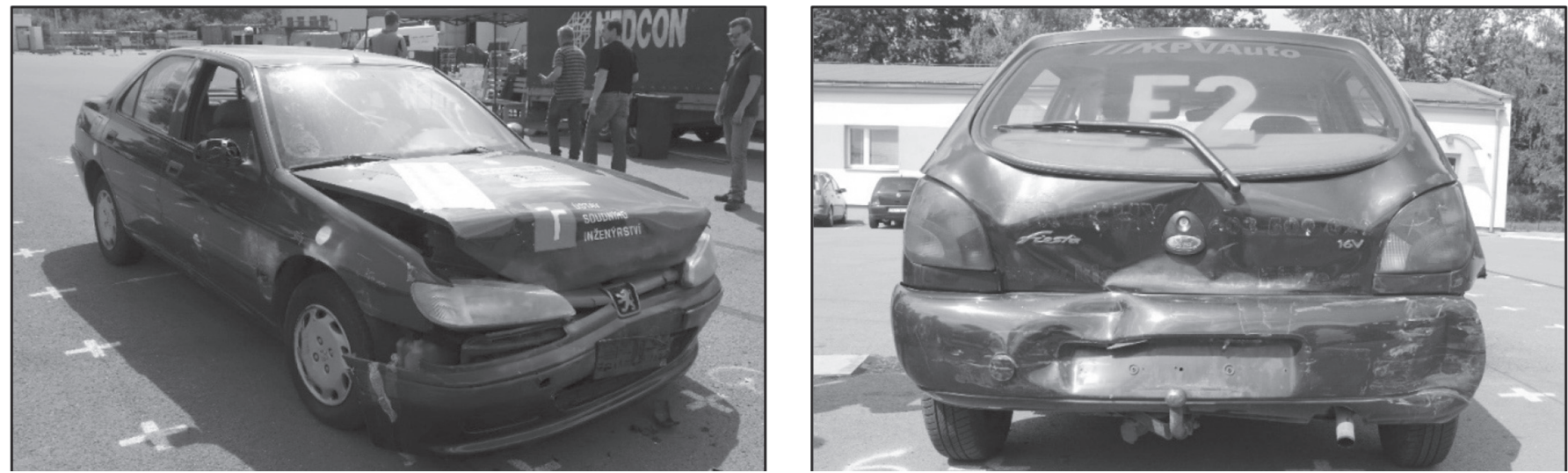

Obr. 25 a 26 Poškození vozidel Peugeot a Ford při prvním nárazu zkouška č. 4 [8].

Fig. 25 and 26 Damage of vehicles Peugeot and Ford at first collision-test No. 4 [8].
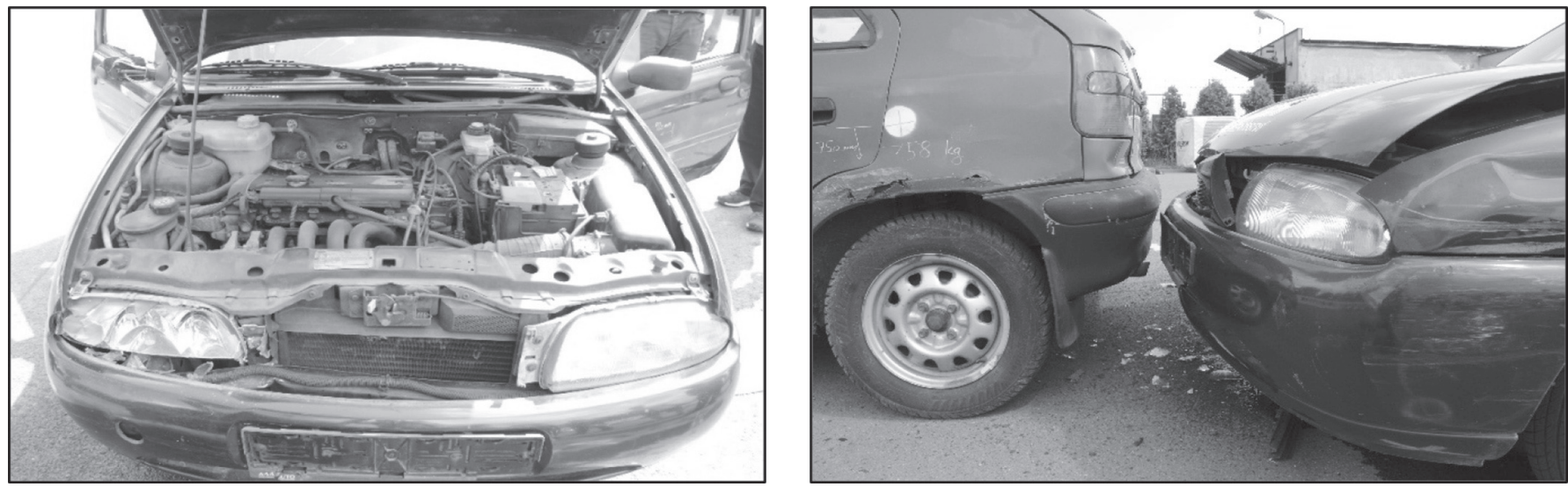

Obr. 27 a 28 Poškozeni vozidel Ford a Škoda při druhém nárazu zkouška č. 4 [8].

Fig. 27 and 28 Damage of vehicles Volkswagen and Skoda at second collision - test No. 4 [8]. 
chvíli již stojícího a brzděného vozidla Ford Fiesta, které bylo nárazem urychleno na rychlost cca $18 \mathrm{~km} / \mathrm{h}$. Touto rychlostí narazilo svou přední částí do zadní části vozidla Škoda Felicia s cca $50 \%$ překrytím. To bylo v důsledku nárazu odhozeno do své konečné polohy. Průběh nárazové zkoušky je znázorněn na obr. 23. Zadokumentované polohy vozidel před nárazem a v konečných polohách jsou na obr. 24; byly pořízeny pomocí kvadrokoptéry.

\subsection{Výsledky testu a poškození vozidel}

V tab. 4 jsou uvedeny pouze základní parametry střetů a postřetových pohybů vozidel. Vlastní analýza deformační energie a poškození vozidel nebyla zcela možná, nebot' chyběly záznamy některých důležitých parametrů. Tato skutečnost nastala v důsledku toho, že tento nárazový test byl již nad rámec původního programu a tedy byl proveden ve značně omezeném čase. Byl zde prezentován pro možnost porovnání s výše uvedenými nárazovými zkouškami stran střetových rychlostí a rozsahu deformací na vozidlech.

\section{ZÁVĚR}

Provedené nárazové zkoušky prokázaly vzájemné vazby mezi způsobem primárního nárazu a sekundárnín nárazem. Zejména způsob nárazu resp. střetová konfigurace vozidel při primárním nárazu určuje intenzitu sekundárního nárazu. Všechny provedené testy byly v obdobných rychlostech pohybujícího se vozidla 30 až $36 \mathrm{~km} / \mathrm{h}$. Vzájemné poměry deformačních energií mezi primárním a sekundárním nárazem byly:

ad 1. u nárazové zkoušky mezi vozidly Opel Vectra, Suzuki Wagon R+ a Škoda Felicia činila deformační energie sekundárního nárazu cca $18 \%$,

ad 2. u nárazové zkoušky mezi vozidly Opel Omega, Volkswagen Golf a Škoda Felicia činila deformační energie sekundárního nárazu cca $14 \%$,

ad 3. u nárazové zkoušky mezi vozidly Citroën Saxo, Volkswagen Golf a autobusu Karosa C 934 činila deformační energie sekundárního nárazu cca $57 \%$,

ad 4. u čtvrtého testu nebyla celková deformační energie stanovena $\mathrm{z}$ důvodu absence některých důležitých parametrů, lze ovšem pouhou komparací porovnat poškození zadních části vozidel Ford a Škoda, které byly velmi obdobné, tudíž intenzita primárního a sekundárního nárazu mohla být také obdobná.
U prvních dvou testů se jednalo u primárního nárazu o takzvaný náraz s malým překrytím a z toho důvodu byla deformační energie sekundárního nárazu výrazně nižší. U dalších dvou testu byl primární náraz s téměř plným překrytím, a proto byla deformační energie sekundárního nárazu výrazně vyšší.

Bylo uvažováno rovnoměrné rozdělení deformační energie pro konkrétní vozidla, na základě tohoto předpokladu a s ohledem na hmotnosti kolizních partnerů byl dopočítán parametr EES pro jednotlivá vozidla. Tento byl dále kontrolován s využitím komparační metody a katalogem EES [4]. Poněvadž se jednalo o starší vozidla obdobné konstrukce jako vozidla uváděná v katalogu, dosahovalo se dobré shody při porovnání rozsahu poškození. Vlastní průběhy nárazových zkoušek byly také řešeny s podporou simulačního programu [3] a vykazovaly velmi dobrou shodu se zadokumentovanými skutečnostmi.

Závěrem je potřeba poděkovat pořadatelům jednotlivých nárazových zkoušek, bez jejichž zapojení by zřejmě nevznikly, dále pak kolegům z Crashteamu ÚSI VUT, díky jejichž vynaloženému úsilí a entuziasmu byly zajištěna data použitá v tomto článku.

\section{LITERATURA}

[1] BRADÁČ, A. a kol.: Soudní inženýrství. Akademické nakladatelství CERM, s.r.o., Brno, Červen 1997 Brno, 725 s. ISBN 80-7204-057-X.

[2] TOKAŘ, S., SEMELA, M., BILÍK, M., BRADÁČ, A. Comparison of selected impal parameters by side vehicle cash tests with computational software results. In: International Conference on Traffic and Transport Engineering ICTTE. Scientific research center Ltd. Belegrade, 2016. s. 634-641. ISBN 978-86-916153-3-8.

[3] Simulační program Virtual CRASH 4, dostupné z www.vcrash3. com

[4] MELEGH, G., VIDA, G. Katalog EES CD 2005. AutoExpert Hungary. 1997-2005.

[5] Nárazová zkoušky Zábřeh na Moravě 2018 - vlastní archiv.

[6] Nárazová zkoušky Pardubice 2012 - vlastní archiv.

[7] Nárazové zkoušky Prostějov 2016 - vlastní archiv.

[8] Nárazové zkoušky Pardubice 2018 - vlastní archiv.

\section{Správná citace:}

TOKǍ̌, S. Ǩetězové nárazy vozidel. Soudní inženýrství, 2019, 30(3), 2-12. DOI: http://dx.doi.org./10.13164/SI.2019.3.2. ISSN 1211-443X. 